\title{
Sovereignty over natural resources - A normative reinterpretation
}

\author{
P E T R A G ÜM P L O V Á iD \\ Max-Weber-Kolleg für kultur- und sozialwissenschaftliche Studien, Universität Erfurt, Postfach 900221, \\ 99105 Erfurt, Germany
}

Email: petra.guemplova@uni-erfurt.de

\begin{abstract}
This article provides a normative account of sovereign rights to natural resources on the basis of moral principles which underlie its international legal structure - the right to self-determination and human rights. The first part locates the emergence of the system of sovereign rights to natural resources in the process of the decolonisation and justifies it as a correction of historical injustice of violent appropriation of natural resources. The second part identifies the key moral component and justificatory principle of the system of sovereign rights to natural resources - the right to self-determination. I outline a justice-based interpretation of the right to selfdetermination and show why rights to natural resources are its corollary. The last part connects rights to self-determination and rights to natural resources to human rights and shows how human rights define the permissible scope of rights to natural resources in two dimensions - the dimension of political legitimacy of the exercise of resource rights and the dimension of the distribution of resource benefits.
\end{abstract}

Keywords: human rights; justice; natural resources; self-determination; sovereignty

Long neglected by critical and normative theorising, natural resources have recently become subject to an increased scrutiny in an ever-expanding field of the philosophy of justice. A common and dominant feature of the available conceptions of natural resource justice is that rights to them are construed exclusively as purely moral rights - rights individuals or collectives have as an implication of a general moral principle or a principle of justice which is to be justified independently of existing institutions, relations, or legal structures.

Here is a very cursory overview of the most influential approaches: Charles Beitz defended rights of states to an equal share of the world's natural resources on the basis of a general principle of international distributive justice derived from a hypothetical social contract. ${ }^{1}$ Hillel Steiner derived

${ }^{1} \mathrm{C}$ Beitz, Political Theory and International Relations (Princeton University Press, Princeton, NJ, 1979) 136-42. 
individual rights to an equal share of the value of natural resources from the ultimate libertarian moral principle of self-ownership. ${ }^{2}$ Mathias Risse derived rights of all humans to have an equal opportunity to satisfy their basic needs through the use of collectively owned natural resources from the natural law principle of the collective ownership of the earth by humankind. ${ }^{3}$ Cara Nine and Margaret Moore have derived notions of collective rights to natural resources from normative theories of territorial rights, justified either by recourse to natural $\mathrm{law}^{4}$ or to a moral right to self-determination. ${ }^{5}$ Most recently, Chris Armstrong has developed a global egalitarian theory of distributive justice centred on a moral principle of an equal access to well-being. ${ }^{6}$

Concerned pre-eminently with purely moral principles and their justification and with the elaboration of normative theories on their basis, these conceptions have left the question of a possible moral status of existing legal rights to natural resources, namely the international system of sovereign rights of states to resources on their territories, unaddressed. Invariably, sovereign rights of states are either dismissed as unjust or unworthy of moral justification or measured against the backdrop of the above-mentioned moral rights. ${ }^{7}$ Allen Buchanan has called this common methodological approach 'the mirroring view'. ${ }^{8}$ The mirroring view is based on a widely shared and uncritically accepted assumption that moral rights are the only proper object of normative philosophical inquiry because they have an ontological and moral priority over legal rights. ${ }^{9}$ Legal rights, if they are subject to

${ }^{2} \mathrm{H}$ Steiner, 'Territorial Justice' in S Caney et al. (eds), National Rights, International Obligations (Westview Press, Boulder, CO, 1996) 139-48; and 'Sharing Mother Nature's Gifts: A Reply to Quong and Miller' (2011) 19(1) Journal of Political Philosophy 110.

3 M Risse, On Global Justice (Princeton University Press, Princeton, NJ, 2012).

${ }^{4}$ C Nine, Global Justice and Territory (Oxford University Press, New York, NY, 2013) $26-39$.

5 M Moore, A Political Theory of Territory (Oxford University Press, New York, NY, 2015) 34-66, 162-72.

6 C Armstrong, Justice and Natural Resources (Oxford University Press, New York, NY, 2017).

7 Armstrong, for example, has argued that territorial sovereignty over natural resources cannot be justified on moral grounds of moral claims of improvement or attachment to resources. See (n 6) 132-76.

8 A Buchanan, The Heart of Human Rights (Oxford University Press, New York, NY, 2013) 14.

9 For a similar point, see A Honneth, Freedom's Right. The Social Foundations of Democratic Life (Polity Press, Cambridge, 2014) 1. Honneth criticises contemporary philosophy and its fixation on purely normative principles decoupled from an analysis of society and from norms prevailing in given practices and institutions. 
moral inquiry at all, have to be theorised only in connection with these antecedent, philosophically justifiable moral rights - they are to be interpreted either as their mirror reflection or judged critically in light of independent moral rights.

I side with Buchanan that the mirroring view is a problematic methodological assumption; and I hold that the exclusive focus on moral rights to natural resources is impractical and morally and epistemologically restrictive. First of all, the emphasis on the centrality and priority of moral rights or principles which are in no way connected to existing institutional structures leads to conceptions whose implications for the practice are limited or unfeasible because they are in an unresolvable conflict with other legitimate institutions (e.g. democratic decisions, collective self-determination, state borders or territorial rights). All above-mentioned conceptions of natural resource justice offer very little guidance on how to resolve the conflict with existing legal rights to resources. ${ }^{10}$ More importantly, they fail to systematically account for what are arguably the most endemic and morally urgent conflicts and problems with natural resources which arise in intrastate context. The first of these problems concerns the abuse of natural resources by illegitimate or corrupt governments and the use of natural resources for the perpetration of injustice such as repression and violence. The second relates to the failures of states to allocate both benefits and burdens arising from the use of natural resources equitably and fairly among multiple constituencies within their borders, especially to historically marginalised communities such as indigenous groups, subsistence farmers, or rural poor, as well as the failures to avoid negative local social and environmental impacts of resource extraction. ${ }^{11}$

Secondly, the insistence on the centrality of practice-independent moral rights severely constrains possibilities of a moral interpretation of existing human institutions and their evaluation from the perspective of their own inherent moral principles. As Buchanan rightly insisted when analysing the international legal system of human rights, legal rights need not be

10 On the inadequacy and impracticability of global distributive justice conceptions focusing on natural resources see T Hayward, 'Global Justice and the Distribution of Natural Resources' (2006) 54 Political Studies 349.

11 Two recent books relying on extensive empirical material demonstrate that these are indeed two broad categories of problems with natural resources which are both endemic and urgent - and are perceived by concerned actors as such. See L Wenar, Blood Oil: Tyrants, Violence, and the Rules that Run the World (Oxford University Press, New York, NY, 2016) and J Gilbert, Natural Resources and Human Rights: An Appraisal (Oxford University Press, New York, NY, 2018) 2-4. 
embodiments or realisations of pre-existing or independently existing moral rights in order to be justifiable or interpretable in moral terms. As instrumental human creations, legal rights serve a number of different worthy purposes and can be justified by appeal to a number of practical considerations many of which may not be directly linked to transcendent moral rights. ${ }^{12}$ Even without an appeal to such moral rights, moral evaluation and justification of institutions is possible - and is in fact desirable provided an assessment of the practice is the goal of the philosophical inquiry.

In this article, I explore precisely this alternative approach to normative theorising. I take sovereign rights of states to natural resources - rights determined by international law and its principle of 'permanent sovereignty over natural resources' (hereafter referred to as PSONR) - as a starting point of normative inquiry about justice and natural resources. I show, first, that the system of sovereign rights is justifiable on functional grounds as a response to the historical injustice of colonial appropriation of natural resources based on violence, domination, and dispossession of natural resources by foreign powers. Secondly, I show that it is possible to reconstruct sovereignty over natural resources from a moral point of view of justice which is inherent in this international legal system itself. By invoking the right to selfdetermination as the core moral principle upon which the system is built, I offer a justice-based reconstruction of sovereignty over natural resources. Finally, by linking the right to self-determination to human rights, its very close relatives, I show what substantive principles of justice are inherent in it.

The approach I utilise can be called 'moral reconstruction'. It aims at providing a form of moral appraisal of the system of sovereignty over natural resources which tries to avoid assessing it from the perspective of abstract or antecedent moral principles constructed and defended by normative philosophical theorising. This method thus neither develops a theory of moral rights to natural resources nor derives a conception of rights to natural resources from transcendent normative principles (e.g. from the principle of the egalitarian distribution or from the principle of common ownership of the earth) or other moral rights (e.g. moral territorial rights). Instead, it attempts to reconstruct existing legal rights to natural resources in terms of their possible justification and by identifying their own underlying moral principles and principles of justice and use them for the clarification and determination of what is the permissible scope of these rights, what is a set of prerogatives and limits, and what are

12 See (n 8) 11, 14-23, 50-74. 
the conditions of legitimate exercise of these rights. ${ }^{13}$ Two methodological precepts, both developed and applied by Allen Buchanan, guide this reconstructive enterprise. The first concerns the application of a 'pluralistic justificatory methodology'. As Buchanan put it, a pluralistic justificatory methodology allows for the possibility of the justification of an institution not on the basis of the correspondence with pre-existing or independent moral rights but instead by appealing to other moral considerations, for example its functions and benefits it delivers. ${ }^{14}$ Human rights as an international legal system are, according to Buchanan, an example of an institution which cannot be expected to 'mirror' independent moral rights. An appeal to functional or instrumental considerations, e.g. the role it plays in correcting injustice, limiting sovereignty, and benefits it delivers, is sufficient for making a moral case for such a system. ${ }^{15}$ Similarly, the system of sovereignty over natural resources may not be justifiable on grounds of available moral rights or principles of justice, e.g. egalitarian distributive principles or moral territorial rights. It does not embody these rights nor can it be judged in light of them. Yet, it may have a legitimate origin and a worthy purpose and this purpose for which it is instrumentally valuable makes it possible to accept it as justifiable.

The second methodological precept concerns the possibility of a justicebased interpretation of international law. In his book Justice, Legitimacy, and Self-Determination: Moral Foundations of International Law, Buchanan showed that the existing international legal system can and ought to be evaluated from the standpoint of its own inherent moral principles, including, pre-eminently, principles of justice. These principles of justice are to be understood primarily as principles that ascribe basic

13 This approach reflects on the debate between traditionalist and practical or political views of human rights. Traditionalist approaches to the philosophy of human rights are typically concerned pre-eminently with human rights as a subset of moral rights and treat human rights as a pre-existing philosophical concept of moral human rights. They therefore take their primary task to be developing a philosophically sound theory of moral human rights, both for its own sake and on the further assumption that such a theory is needed to guide or reform the practice. By contrast, practical or political views accord the existing international legal system of human rights a central significance in setting the agenda for normative reflection. For the reconstruction of this debate, see K Hessler, 'Theory, Politics, and Practice: Methodological Pluralism in the Philosophy of Human Rights' in R Maliks and J Schaffer (eds), Moral and Political Conceptions of Human Rights: Implications for Theory and Practice (Cambridge University Press, Cambridge 2017) 15-32. See also (n 8) 3-22.

14 See (n 8) 43, 55.

15 According to Buchanan, human rights are legal instruments which serve a number of purposes, most importantly to constrain sovereignty by affirming the equal moral status of all people and prescribing states the duty to ensure that all have an opportunity to lead minimally good or decent life. See (n 8) 68. 
human rights to all persons. ${ }^{16}$ Accepting the possibility and plausibility of a justice-based account of international law, I focus on the right to selfdetermination as the key principle of justice embedded in the international law system of sovereignty over natural resources. Analysing its reinvention and legalisation within the system of human rights in the postwar international politics, I show how the interpretation of the right to selfdetermination helps to develop a normative conception of the permissible scope of sovereign rights to natural resources and how, with the help of human rights, substantive principles of justice can be specified along two dimensions - the dimension of political legitimacy of the exercise of rights to natural resources and the distributive dimension of the allocation of benefits arising from the use of natural resources.

Since this is an approach not yet applied in the debate about natural resource justice, let me offer a few more reasons why to pursue it. Beyond a simple yet compelling reason that there is a dominant and widely accepted system of sovereign territorial rights to natural resources which has not yet been subject to a comprehensive moral and justificatory analysis from the perspective of justice before, there is another reason. To the extent to which one accepts an ethical conviction that philosophy should be practice-oriented and shed light on the practice, making sense of an existing system which is central to the practice appears to be a prominent task for philosophy. ${ }^{17}$ This ethical conviction can be paired with an emphasis on two further criteria which make this approach preferable to the approach of the construction of moral rights employed in the current debate about natural resources.

The first concerns the plausibility of the criteria of criticism and the superiority of immanent criticism over the mirroring view. Current state practice regarding natural resources surely produces many severe injustices. As mentioned, illegitimate governments using natural resources unjustly and for unjust ends and states failing to fairly distribute benefits and burdens arising from resource exploitation are the most urgent ones. The response of a critically oriented philosophy, however, is not to dismiss sovereignty over natural resources as morally defective and fundamentally ill-placed to respond to any demands of justice, but to provide a systematic moral reconstruction of it, followed by the critique of how it is 'practised' based on these immanent moral criteria.

16 A Buchanan, Justice, Legitimacy, and Self-Determination: Moral Foundations for International Law (Oxford University Press, New York, NY, 2004) 4.

17 Beitz made a strong case for the philosophical theorising which is useful for the assessment of the practice; and suggested that philosophy should begin with the accurate characterisation of it; C Beitz, The Idea of Human Rights (Oxford University Press, New York, NY, 2009) 7-10. See also (n 8) 22. 
The second criterion concerns the issue of the feasibility and practicability of a possible reform. As Buchanan argued, legality and legal rights have a great advantage over direct appeals to transcendent morality because the morality legal rights embody reflects an accessible, acceptable, and negotiated vision of what is just. This is clearly the case of international human rights law which represents a universally accessible version of global moral lingua franca to which various parties appeal and which also includes a vast and complex system of norm making, compliance monitoring, enforcement, and guidelines for a change. But it is also the case, as I will show, of sovereign territorial rights to natural resources. They are based on a negotiated and shared insight that territorially situated collectives need to be able to control their natural resources because the control over them is a key component of political self-determination and a bulwark against predatory economic powers and because those groups are privileged in using them for their collective benefit. An appeal to this notion and the possibility to connect it with human rights yields practicable notions about how states ought to use their natural resources. ${ }^{18}$

Here is the roadmap: in the first section, I locate the emergence of the system of sovereign rights of states to natural resources in the process of decolonisation. I address the question of its historical justification and its purpose to correct colonial injustice. In the next section, I identify its key moral component - the right to self-determination. This part delivers a justice-based interpretation of the right to self-determination and shows why rights to natural resources are its corollary. The third part discusses how the right to self-determination is inextricably connected with human rights and how human rights are the key to specifying a conception of natural resource justice in two of its fundamental dimensions - the political dimension of legitimacy of decision-making authority over natural resources and the distributive dimension of the allocation of resource benefits to groups and individuals.

An important caveat about the scope of my analysis is necessary here. My aim is limited to a moral reconstruction of the legal system of sovereign rights to natural resources, with a more specific goal to outline a possible conception of natural resource justice underlying it. My objective is not to develop a comprehensive theory of natural resource justice addressing all possible areas of resource use. I also by no means intend to defend the system of sovereign rights as the best possible. The task of identifying a possible moral justification and a moral core of the system of sovereignty

${ }^{18}$ I agree with Buchanan that notions derived from legal rights are more likely successful in influencing the behaviour of states or relevant actors as they usually involve mechanisms of compliance and enforcement. See (n 8) 7-9. 
over natural resources and interpreting it from the point of view of justice is guided by an attempt to address critically and with a view to a possible reform what I consider the most endemic and pressing problems with natural resources resulting from states' misuse of their resource sovereignty privilege - the illegitimate use of natural resources for the perpetration of injustice and the failure to ensure a fair distribution of benefits and burdens arising from resource extraction. Correspondingly, an account of what limits states in their exercise of sovereignty over natural resources is being offered here, such that relies on principles of justice underlying the international legal system itself. While this account sidelines questions of global distributive justice raised by some of the philosophers named above, it offers a more systematic and robust critical reconstruction of the dominant system of sovereignty over natural resources which can contribute substantially to a more just use of natural resources.

\section{The origin of sovereign rights over natural resources}

The system of permanent sovereignty over natural resources in which sovereign rights over natural resources belong equally to all states and their people is relatively new. It is not merely an implication of territorial rights of states or a corollary of the territorial integrity of states. ${ }^{19}$ Its provenance lies in the United Nations and it is an outcome of a political process of international law-making in the postwar period tied to the process of decolonisation. The historical context of the building of a new international order out of the colonial system in which foreign political powers and private individuals and companies unjustly appropriated natural resources occurring on territories of colonised peoples is the key to its understanding and justification.

In the colonial period, rights to natural resources in the non-European world were acquired by colonial powers through several mechanisms authorised by or, more precisely, constitutive of the emerging law of nations. The right of conquest, one of the oldest rules of international relations, justified unlimited military campaigns in distant foreign territories for the purpose of the imposition of political domination and accumulation

19 Sovereign claims to natural resources did exist before the introduction of the system of permanent sovereignty. Their pedigree is linked to the emergence of absolutist sovereignty in Europe and colonialism. A system in which rights to natural resources are a part and parcel of a set of rights and prerogatives involved in sovereignty and belong equally and inalienably to every sovereign entity in a system of international law exists, however, only since the introduction of PSONR in 1960s. See A Scott, The Evolution of Resource Property Rights (Oxford University Press, New York, NY, 2008). 
of natural resources for the exclusive benefit of the colonial sovereign or a private trading company. ${ }^{20}$ The doctrine of discovery and occupation, invented to provide an alternative justification for colonial projects and to facilitate the resolution of conflicts among them, authorised Europeans to acquire territorial and property rights merely in virtue of the 'discovery' and settlement. Even if territories were already occupied, settlers automatically acquired property rights to lands and resources and gained governmental, political, and commercial rights over the native inhabitants. ${ }^{21}$ The freedom of navigation, trade and commerce defended by Europeans as universal rules of natural law justified the practice of enforcing nonreciprocal and asymmetrical treaties, concessions, and contracts which granted extensive and exclusive extraterritorial powers over people, property, and resources to European sovereigns, trading companies, or even private individuals. ${ }^{22}$

These legal and political regimes and technologies were designed to justify and enable the domination over distant people and the exploitation of their natural resources. They facilitated the establishment of ownership regimes and property rights to natural resources which perpetrated, with varying degrees, several fundamental injustices: the injustice of violence and the destruction of rights of others and its giving rise to legal rights to territory and natural resources, the injustice of exclusion and radical inequality in distribution of opportunities, benefits, and burdens related to the use of natural resources (e.g. using slavery or racialised systems of forced labour to exploit natural resources), the injustice related to fraudulent and asymmetrical, non-reciprocal contracts and forceful trading relations, and political injustice of using natural resources for the exclusive benefit of the sovereign and the maintenance of his or her imperial rule.

The system of sovereign rights to natural resources needs to be accounted for by the reference to the correction of this global colonial system which for centuries enabled European sovereigns and their companies and private

20 Traditional right of conquest, employed for example by Spanish crown in the early 15 th century to create an empire in America, enabled killing of civilians, destroying and confiscating of their property, and enslaving of the prisoners of war. S Korman, The Right of Conquest (Clarendon Press, Oxford, 1996) 29-30.

21 Property rights to lands and other natural resources were also transferred to colonisers through contracts which were more often than not imposed on locals through coercion. RJ Miller, J Ruru, L Behrendt and T Lindberg, Discovering Indigenous Lands: The Doctrine of Discovery in the English Colonies (Oxford University Press, New York, NY, 2010) 19-22.

22 Trading companies such as British East India Company or Dutch East India Company obtained extensive trading privileges and rights of political jurisdiction through a combination of treaties, concessions from local rulers, and military conquest. See eg PJ Stern, The CompanyState: Corporate Sovereignty and the Early Modern Foundations of the British Empire in India (Oxford University Press, New York, NY, 2011). 


\section{PETRA GÜMPLOVÁ}

individuals to unjustly appropriate or dispossess natural resources occurring on distant territories of other peoples and populations. To correct this global colonial system, it allocated sovereign rights to natural resources to territorial collectives, providing them a legal tool against foreign companies or powers and their efforts to exploit resources for their own benefit and to establish extensive property rights not subjected to regulation by local jurisdictions. National ownership of natural resources, or the 'permanent sovereignty over natural resources' as the new principle was named, legally protected by international law was unambiguously understood as the bulwark against these predatory colonial powers, onerous and inequitable contractual arrangements, as well as an essential prerequisite of the political autonomy and economic development.

Of course, the permanent sovereignty over natural resources was prominently advocated by newly independent and developing countries who asserted that they have an inherent right to utilise and exploit their own natural resources and wealth. They claimed their sovereignty over natural resources as inherently implied in the right to collective selfdetermination - a newly invoked and reinvented principle which assumed a central place in the postwar international law by ascribing all peoples an inalienable and equal right to freely determine their political status and freely pursue their economic, social, and cultural development without any interference in any form by another state. ${ }^{23}$ However, claims to national ownership of natural resources were accepted by the majority of international actors not only as a way of correction of historical injustice but also because of the widely shared view that an equal right to a full control and free use of natural resources by nations are a crucial element of political autonomy and instrumental for a country's economic development. ${ }^{24}$

At the beginning of the 1960s, as Schrijver documents, the legalisation of the principle of permanent sovereignty over natural resources was supported by most countries at the United Nations. It was facilitated by the UN General Assembly and occurred mainly through resolutions of international political organs adopted as a result of a participatory, inclusive, and deliberative process. ${ }^{25}$ The consensus and the essence of the

23 This formulation is included in many international law sources, e.g. in The Declaration on the Granting of Independence to Colonial Countries and Peoples, GA Res 1514, UN GAOR, 15th Sess., Supp. No. 16, UN Doc A/L.323 and Add. 1-6 (1960).

${ }^{24}$ N Schrijver, 'Self-Determination of Peoples and Sovereignty over Natural Wealth and Resources' in Realizing the Right to Development (United Nations Publication, New York, NY, 2013) 96.

25 Schrijver's detailed study demonstrates this point; N Schrijver, Sovereignty over Natural Resources (Cambridge University Press, New York, NY, 1997) 33-80. 
system of sovereign rights to natural resources is articulated in the UN General Assembly Resolution 1803 adopted in 1962 which provides that states and their people have a 'permanent sovereignty over natural resources' and that resource sovereignty is 'a basic constituent of the right to self-determination'. ${ }^{26}$ The new norm of PSONR legally protects the sovereign's decisional autonomy over natural resources and grants them an extensive bundle of exclusive powers and prerogatives - the right to legislate and adjudicate property rights and management rules over natural resources, rights to sell natural resources, decide on terms of foreign investment and extraction contracts, and nationalise foreign property. ${ }^{27}$

Following the process of the legalisation, the principle of permanent sovereignty has developed into a widely accepted norm of international law. It has become a dominant type of jurisdiction over natural resources on earth. It has comprised all natural wealth, resources, and economic activities on, above, and below the territories of sovereign states. During the 1980s, it expanded further into areas that were previously international (high seas) or had no jurisdiction whatsoever (seabed and its subsoil). It has evolved into a key prerogative attached to state sovereignty, precluding the state from derogating from the essence of the exercise of its sovereign rights over its natural resources. Today, the principle of permanent sovereignty over natural resources represents one of the bedrock principles of international law, underlying most regimes of international law, e.g. international environmental law, international economic law, and the law of the sea.

To sum up: the introduction of the system of sovereign rights to natural resources represented the single most profound and consequential international reform concerning ownership, control, and use of land and natural resources. It emerged as a legal correction of the injustice of colonial appropriation of natural resources which consisted in unilateral and ruthless exploitation and dispossession of resources by foreign powers and was linked to violence, domination, exclusion, and inequality. By legalising a set of prerogatives and immunities, most importantly the right to exercise the ultimate jurisdiction over resources or the right to nationalise foreign or private property, PSONR provided legal instrument for the annulment of the private property rights or contractual terms imposed illegitimately or illegally by foreign states or companies. Beyond the function of an immediate correction of injustice, PSONR also aimed at economically reinforcing the process of political self-determination of

\footnotetext{
26 Permanent Sovereignty over Natural Resources, GA Res 1803, 14 December 1962. 17 GAOR, Supp. 17, UN Doc A/5217, 15.

27 See (n 25) 263.
} 
colonised peoples and at boosting economic development of developing countries. To protect political control over the natural environment and its resources and secure economic benefits from the exploitation of natural resources for a country's people can be unambiguously identified as its moral core.

This surely is a justification of the system of sovereign territorial rights over natural resources. It is not a kind of moral justification contemporary philosophy has preferred, relying on moral principles or principles of justice construed by practice-independent moral reasoning and defensible independently of norms prevailing in practices and institutions. PSONR may or may not be an embodiment of such moral rights. According to the pluralistic justificatory methodology, there is no need to appeal to antecedently existing moral rights and to look for their mirror reflection in the practice. It is also implausible to use such rights to judge its moral status. PSONR is a historically unique international legal system which is to be justified chiefly by appeal to the function it performs - to allocate to territorially situated political collectives jurisdictional and ownership rights to natural resources occurring on their territory for the sake of preventing their unjust uses by others and for the sake of protecting their privileged access to benefits arising from their use. This function is sufficient to endow it with moral status.

In the next section, I would like to suggest a more systematic moral reconstruction of the system of sovereign rights to natural resources which goes beyond the explanatory historical justification emphasising the correction of historical injustice of colonialism. This task will be fulfilled by engaging in a justice-based normative reconstruction of the right to selfdetermination - the moral core and the justificatory principle of the doctrine of the permanent sovereignty over natural resources and hence the new system of sovereign rights to natural resources. I argue that the reconstruction of the right to self-determination offers a coherent normative foundation for sovereignty over natural resources. It enables to clarify who and why is the holder of rights to natural resources and what is a content of such right. The possibility to link the right to self-determination to human rights will then enable to specify the permissible scope of sovereignty over natural resources and the procedural and substantive principles of justice inherent in it.

\section{Justice-based interpretation of the legal right to self-determination}

As a political claim, self-determination has a long history. In the period during World War I, the principle of self-determination was used to express aspirations of ethnically defined groups and minorities for nationality. However, in the process of post-World War I realignment, 
the principle was subordinated to other concerns and geopolitical interests. The notion that ethnically defined nations have the right to selfdetermination was further undermined by the savagery of the Nazi attempt to create an ethnically homogeneous Germany. As Christian Reus-Smit put it, the principle of self-determination emerged from World War II 'politically and ethically denuded' and 'morally bankrupt'. ${ }^{28}$ It had to be reinvented to suit the emancipatory politics of the decolonisation and the profound transformation of international order toward a system of equally sovereign states.

In order to assume the central place in this process - the process of the most profound political realignment of the international order in modern history - self-determination was reinvented from a political principle into a legal right. This evolution, as Hurst Hannum points out, is marked by the General Assembly's 1960 Declaration on the Granting of Independence to Colonial Countries and Peoples. ${ }^{29}$ This Declaration states that the continued existence of colonialism prevents the international cooperation, impedes social and economic development, and militates against the UN ideal of peace and fundamental human rights. It declares that 'all peoples have the right to self-determination' and that 'by virtue of that right they freely determine their political status and freely pursue their economic, social and cultural development'. It also affirms that 'peoples may, for their own ends, freely dispose of their natural wealth and resources'. ${ }^{30}$

As Reus-Smit pointed out, the overall process of the reinvention of the normative foundations of self-determination took place in the broader context of the negotiations of the United Nations Human Rights Covenants. The 'new' right to self-determination was grafted on to emergent human rights norms and asserted as necessary to the satisfaction of human rights - with postcolonial states having played a prominent role in this campaign. ${ }^{31}$ Legally binding the International Covenant on Civil and Political Rights and the International Covenant on Economic, Social and Cultural Rights reveal this connection and manifest the mutually constitutive, co-original link between self-determination, sovereignty over natural resources, and human rights. Article 1 in both

28 C Reus-Smit, Individual Rights and the Making of the International System (Cambridge University Press, Cambridge, 2013) 169-70.

${ }^{29}$ H Hannum, 'Rethinking Self-Determination' (1993) 34(1) Virginia Journal of International Law 12.

30 The Declaration on the Granting of Independence to Colonial Countries and Peoples, GA Res. 1514, UN GAOR, 15th Sess., Supp. No. 16, UN Doc A/L.323 and Add. 1-6 (1960).

31 See (n 28) 10, 153-60, 169-70, 180-7. The same point was emphasised by SLB Jensen, The Making of International Human Rights: The 1960s, Decolonization, and the Reconstruction of Global Values (Cambridge University Press, New York, NY, 2017). 
covenants states, along the lines of the above-mentioned Declaration on Colonial Independence, that 'all peoples have the right to self-determination' and that 'by virtue of that right they freely determine their political status and freely pursue their economic, social, and cultural development'. In the next sentence, it states that 'all peoples may, for their own ends, freely dispose of their natural wealth and resources without prejudice to any obligations arising out of international economic cooperation, based upon the principle of mutual benefit, and international law. In no case may a people be deprived of its own means of subsistence. ${ }^{32}$

The fact that the right to self-determination and the resource sovereignty as its corollary are included in human rights covenants - and are thus made part of human rights law-implies that there is a mutually reinforcing between these fundamental norms of international law. The link means that the scope of the right to self-determination and, by extension, the scope of sovereign rights to natural resources is to be determined and interpreted in terms of human rights. The association with human rights also enables to interpret the meaning of the right to self-determination beyond the decolonisation context and to insist that any self-determining collective, even the one which has already been self-determined by becoming independent, ought to aspire to an internal self-determination via representative government, democracy, and human rights. I will return to this connection and the implications thereof below. Let me now continue with the justice-based interpretation of the right to self-determination which I pursue in order to explain the possible normative foundation of the existing sovereignty over natural resources.

\section{The who and what of self-determination}

The law and the practice of the right to self-determination in the process of the decolonisation was based on a distinct approach to defining the holder of the right to self-determination which can perhaps be called 'political-territorial'. It allocated the right to self-determination not to minorities or groups with common ethnic, linguistic, and religious characteristics but to 'all peoples', with a special emphasis on colonised peoples, i.e. territorial groups subjected to territorial domination, alien subjugation, and exploitation. Colonised peoples, the most prominent holders of the right to self-determination, were more often than not multiethnic or multi-religious groups united essentially by their political identity

32 Covenant on Economic, Social and Cultural Rights, Annex to General Assembly Resolution 2200 (XXI), 16 December 1966; and International Covenant on Civil and Political Rights, Annex to General Assembly Resolution 2200 (XXI), 16 December 1966. The Covenants entered into force on 3 January and 23 March 1976, respectively. 
of being subject to foreign territorial domination. In the context of the process of decolonisation, the subject of the right to self-determination thus referred prominently to a group occupying a territory and with a political identity primarily defined by being unjustly dominated by a foreign oppressor state.

This is a distinct territorial approach to determining the holder of the right to self-determination which defines political identity of the people by the injustice of oppression and domination, not by ethnic or cultural identity. The reasons why this approach to decolonisation was preferred were pragmatic and they had to do with widely shared insight that keeping already established and stabilised administrative boundaries is instrumental to the efforts of maintaining peace and promoting international cooperation. Moreover, the protection of ethnic minorities within states was supposed to be achieved by human rights, especially civil and political rights, and other minority rights. That is why the process of decolonisation respected the principle of $u t i$ possidetis which provided that newly formed states accept the boundaries inherited from the previous governing power; and that these are the boundaries of self-determining units which shall trump any aspirations of ethnic groups within those boundaries. ${ }^{33}$ Of course, this approach had many critics who pointed out complications and inconsistencies in its application and its troubling consequences, most importantly concerning the failure to sufficiently address the needs and aspirations of minorities and other potentially self-determining groups trapped in both old and newly created states. ${ }^{34}$

According to international law, the holder of the right to selfdetermination is thus a territorial collective with a political identity primarily derived from a rightful demand of this collective to establish justice for its members. To reflect on this distinct political-territorial approach involved in the international legal right to self-determination, I will refer to the holder of the right to self-determination as a 'selfdetermining territorial group', emphasising thereby the fact that the most 'peoples' and nations in the postwar international system are ethnically pluralistic entities on the one hand, and that these entities and their rights to self-determination are circumscribed within clearly demarcated territorial space.

33 As Zacher showed, the relatively consensual acceptance of the principle of uti possidetis can be explained by the widely shared opposition to irredentism and border revisionism which reflected the insight that territorial disputes are the major cause of armed conflict and correlate with frequency and intensity of war. M Zacher, 'The Territorial Integrity Norm: International Boundaries and the Use of Force' (2001) 55(2) International Organization 215.

34 A Cassese, Self-Determination of Peoples: A Legal Reappraisal (Cambridge University Press, Cambridge, 1995) 74. See also (n 29) 35-9. 
Justice is the key to defining the political identity of a self-determining group as defined by international law. What does justice refer to? On the most profound level, justice involved in the legal right to self-determination refers to a remedy for a deep injustice of colonialism. The injustice of colonialism did not involve merely the lack of consent with the colonial rule but a more fundamental injustice related to the arbitrariness of the interference in domestic affairs, the subjugation of colonised peoples to a subordinate status, the domination, and institutionalisation of relationship of political, social, economic dependence. In practice, these unjust features of colonialism ranged from slavery, racial segregation, and other forms of discrimination based on race and religion and on the level of social development, the dispossession of natural resources, and other forms of economic abuse or human exploitation, and, of course, political domination and paternalism.

To go beyond the notion of the corrective justice and specify the content of justice further can be achieved by focusing on the content and the institutional expression of the right to self-determination. At the outset of the decolonisation process, international law has foreseen several modes of implementation of the right to self-determination, including the integration with an existing state. In the practice, however, sovereignty and independent statehood have become dominant forms of the fulfilment of the right to self-determination. The main reason is that sovereign statehood gives institutional expression to the claim to the supremacy of political authority and its exclusive jurisdiction over a population within a territory (sovereignty) and to the claim to external independence of this political authority, integrity, and non-interference from the outside (independent statehood) without which self-determination loses its meaning.

The right to self-determination thus implies not only a 'negative' or immunity right to be free from an external domination but also, and correspondingly, a 'positive' right to establish and maintain separate political institutions, to create a polity which governs itself within a territory. The right to self-determination is essentially a right to a self-rule stemming from a highest political authority endowed with jurisdictional rights to make, legislate, adjudicate, and enforce the rule of law and allocate rights and duties of justice to all members of the territorial collective, most importantly by determining individual and minority rights, by allocating and regulating property rights, and by determining the division of other advantages from social cooperation. This is a distinct political dimension of justice in the right to self-determination, namely that a self-determining collective establishes its own political authority endowed with the right to rule and whose most fundamental benchmark of legitimacy is that it is not foreign. 
The right to establish and maintain a territorial sphere of jurisdiction derived from a supreme and independent public authority can be said to represent the very core of the right to self-determination. However, the right to self-determination also involves rights over natural resources. Why? There is a twofold explanation of why this has come to be the case. One explanation concerns political justice, the other concerns distributive justice.

The first explanation why the right to self-determination has come to involve sovereignty over natural resources is that natural resources are an inextricable part of the territorial environment within which self-determination occurs. Geographical surroundings have substantial importance and impact on most aspects of people's lives. The use of natural resources always involves profound consequences on surrounding environment and the livelihood of the people and hence on their ability to be self-determining. That is why self-determining territorial groups ought to have a supreme authority in making decisions about how to use natural resources on their territories. ${ }^{35}$ When natural resources are subject to extraterritorial property or contractual rights claimed by foreign entities or individuals who make decisions about them in their self-interest and self-determining groups have no say in those decisions or are unable to control those decisions, injustice ensues by definition. Self-determining collectives if they are to be self-determining need to have the powers to make autonomous decisions about their natural environment based on whatever value it has for them - symbolic, environmental, or economic.

The second explanation why politically self-determining groups were granted supreme rights over natural resources in their territory is that a group's ability to be self-determining fundamentally depends on their access to material benefits natural resources provide. Natural resources are instrumental to the fulfilment of the individual basic needs and to collective economic welfare or, to put in Rawls' terms, to create a 'basic structure' and sustain it. ${ }^{36}$ This surely applies to a special category of natural resources which are non-substitutable supports for basic human needs and basic human rights - water, clean air, and soil. Other valuable natural resources such as minerals or fossil fuels provide an important source of economic value for a society and hence resources for sustaining the system of justice. Albeit in complex and mediated ways, they fuel economic development and can be a great advantage for a society. ${ }^{37}$ Groups on whose territory resources occur are privileged in enjoying these benefits.

35 Similar points albeit on strictly practice-independent moral grounds were made by Nine and Moore. See (n 4) 9-12, 32-3, 116-20 and (n 5) 164-6, 174-6.

36 J Rawls, A Theory of Justice (Harvard University Press, Cambridge, MA, 1971) 7.

37 For more on this point see (n 6) 45-52. 
Their ability to fulfil their basic needs and sustain material welfare cannot depend on resources located on some other group's territory or on decisions of other groups of individuals from different territories. ${ }^{38}$ Moreover, since there is no universal notion of economic well-being and there are a number of ways to exploit natural resources, territorial groups need to be able to make decisions themselves about how exactly they want to benefit from natural resources.

Let me reiterate that this is an interpretation - an interpretation couched in the language of justice - of the link between the right to self-determination and sovereignty over natural resources as it underlies current international law which I am not defending here as the best system possible from a transcendent moral point of view. Also, both the decisional autonomy and the privileged access to natural resource benefits which belong to selfdetermining groups ought to be and indeed are subject to several internal limits and external constraints which I will address in the next section. ${ }^{39}$ Let me sum up this part first. Shaped by the postwar reinvention of international law, the right to self-determination emerged as a collective territorial right which allocated to collectives with territorial-political identity two fundamental powers - the right of political jurisdiction and the collective ownership of natural resources within a territory. The first refers to the right to a self-rule stemming from a highest political authority endowed with jurisdictional rights to make, legislate, adjudicate, and enforce the rule of law within a territory and allocate rights and duties of justice to all members of the territorial collective. The second essentially means the ultimate control, decisional autonomy, and privileged use of natural resources and benefits they provide in a given territory.

${ }^{38}$ It has been recognised by a number of scholars that the legalisation of sovereign rights over resources aimed at ensuring that peoples that had lived under colonial exploitation could now gain their rights to exclusively benefit from the exploitation of the resources found within their territories. The claim to be privileged in economically benefiting from natural resources explains why sovereignty over natural resources accorded every state the right to freely exercise full permanent sovereignty, including possession, use and disposal, over all its wealth, natural resources and economic activities. See e.g. J Gilbert, 'The Right to Freely Dispose of Natural Resources: Utopia or Forgotten Right?' (2013) 31(2) Netherlands Quarterly of Human Rights 318-20 and K Gess, 'Permanent Sovereignty over Natural Resources: An Analytical Review of the United Nations Declaration and Its Genesis' (1964) 13(2) International \& Comparative Law Quarterly 398.

39 An important set of constraints concerns cases where two states share a transboundary resource - river systems, lakes, rainforests etc. The same international law which allocates permanent sovereignty over natural resources to states and their people also obliges them not to use or permit the use of its territory in such a manner as to cause transboundary harm. The absolute jurisdiction is impermissible, except on the condition of, or by way of, an agreement of concerned parties. See (n 25) 237. 
These powers over resources have been justified by a shared insight that political self-determination is inseparable from the ability to control the territorial environment and from the necessity to have a privileged access to benefits natural resources provide so that basic needs and demands of social justice can be met. This 'twin' right entailed in the right to self-determination - political authority with territorial jurisdiction and collective ownership of natural resources - points to two fundamental dimensions of natural resource justice, namely the political dimension of legitimacy of decision-making power over natural resources and the social and economic or distributive dimension of the allocation of resources to individuals and groups within states. What remains to be discussed in greater detail are the substantive principles of these two dimensions of natural resource justice.

\section{The scope of sovereign resource rights}

In the global justice debate, a few thinkers have lately invoked the right to self-determination as an important moral constraint on the duties of global distributive justice, especially when natural resources are considered to be a prominent distributive good. Margaret Moore placed the moral principle of political self-determination in the very centre of her normative theory of territorial rights. Allocating self-determination to a 'people' (a group with a distinct political identity, the capacity to maintain political institutions and a history of political cooperation), she argued that self-determination involves both the capacity to establish political institutions (right of jurisdiction) and the control over territory and natural resources. The main reason why self-determination implies control over resources is, according to Moore, that the extraction and the use of resources impinge on many different aspects of the collective life of the community. Therefore, the right to control resources, a corollary of self-determination, is not up for a global redistribution. Responding to global justice thinkers and their arguments for a global redistribution of natural resources, Moore argued that the right to control territorially circumscribed resources by a people may indeed be limited by distributive demands of outsiders whose rights to basic subsistence are at stake. ${ }^{40}$

In a similar vein, Cara Nine defended collective rights over resources as implied in territorial rights. Both thinkers, however, conceive of territorial rights as purely moral rights, not making any reference to existing territorial rights and to international legal right to self-determination and 
its connection with sovereignty over natural resources. Existing legal rights and international law and practice neither inform the elaboration of these normative conceptions and their meaning and content, nor it is suggested what ramifications the proposed normative conceptions might have for the redefinition of the scope of existing legal rights to territory, selfdetermination, and natural resources. Most importantly, Moore and Nine do not specify the self-determination and hence rights over resources in terms of their permissible scope, conditions of their legitimate exercise, and substantive internal limits on these rights. According to Nine, legitimate use of resources by territorial groups is such that serves the purpose of achieving political justice. Yet, she explicitly rejects that consent or democratic approval - principles legitimising authority over persons have any bearing on legitimate authority over resources. In her view, political justice can at best be defined in terms of minimum requirements for self-determining groups to meet the basic needs of their individual members. ${ }^{41}$

The major weakness of the available conceptions of resource rights justified by recourse to moral right to self-determination is thus that they do not provide substantive principles of distributive and political justice relevant for the exercise of resource rights and hence are unable to distinguish when self-determining groups use their natural resources justly and when not. This distinction is, however, very important - not every use of natural resources serves a just purpose and can be justified, certainly not when resources are used to sustain repression or perpetrate injustice such as violence or when resource extraction harms members or other selfdetermining peoples. The reconstructive approach to the legal right to selfdetermination I endorse enables to specify substantive criteria of justice in two fundamental dimensions - the dimension of political legitimacy of the exercise of resource rights and the dimension of the distribution of resource benefits within self-determining groups. These dimensions correspond to two fundamental powers over resources which are implied in the right to self-determination - the right of political jurisdiction and the collective ownership of natural resources within a territory. The specification of more substantive criteria of justice is possible by linking the international legal right to self-determination to human rights. Two arguments can be made to support the connection between self-determination and human rights. The first argument concerns the nature of contemporary international law itself and the possibility to interpret its key norms including the right to self-determination and human rights - from the 
perspective of justice. International law, to be sure, is a complex system which has evolved quite incoherently over centuries. Its key feature, as Patrick Macklem has argued, has been to bring legal order to global politics by distributing and legally authorising the exercise of sovereign power by entities it has recognised as states. By doing so, the international legal order has always displayed serious flaws which Macklem attributes to the extensive latitude that the traditional legal order conferred on states in the exercise of their sovereignty. ${ }^{42}$ Indeed, what Buchanan calls 'traditional international law' ascribed extensive and dangerous prerogatives and immunities to states and imposed no limits on states and persons representing their governments. States had the right to go to war, the right against the interference in domestic affairs, and the right to colonise foreign territories. Individuals were not recognised as having rights on their own account and there was no protection against tyrannical governments. ${ }^{43}$

Contemporary international law reinvented after World War II articulates a number of rules and limits on state sovereignty. Internally or domestically, international law accords an extensive set of individual rights to all human beings and imposes legal duties and obligations on states to fulfil them. Externally or internationally, there are rules which recognise fundamental equality of the right to self-determination and sovereignty of states and prohibit the use of aggressive force and intervention in the internal affairs of other states. ${ }^{44}$ When perceived as a system which not only distributes sovereignty as a legal entitlement but also as a system which extensively regulates its internal and external exercise, international law can be interpreted as a system articulating a relatively coherent notion of justice for the world organised into sovereign territorial states. ${ }^{45}$

42 P Macklem, The Sovereignty of Human Rights (Oxford University Press, New York, NY, 2015) 24, 46. Similar point was made by Beitz (n 17) 65 and Buchanan (n 8) 125.

43 See (n 8) 121-5.

44 The following rules are listed in the Declaration on Principles of International Law Concerning Friendly Relations and Cooperation Among States in Accordance with the Charter of the United Nations which is considered to articulate jus cogens norms of international law: the prohibition of the use of force, non-intervention, equal rights and self-determination of peoples, sovereign equality of states, good faith, peaceful settlement of disputes, duty of economic and social cooperation, and respect for international law. GA Res 2625, UN GAOR, 25th Sess., Supp. No. 18, UN Doc A/8018, (New York, 1970) 124. See also A Cassese, International Law (Oxford University Press, Oxford, 2001) 87-8.

45 Steven Ratner has also argued that international law, peace and human rights being its central aspects, is based on a coherent notion of justice which he called 'thin justice of international law'. S Ratner, Thin Justice of International Law: A Moral Reckoning of the Law of Nations (Oxford University Press, New York, NY, 2015). 


\section{PETRA GÜMPLOVÁ}

A number of scholars have recently argued that human rights international legal rights which ascribe a set of civil, political, social, and economic rights to all persons regardless of their nationality, residence, national or ethnic origin, religion, or any other status or membership in political collectives - can be and ought to be regarded as the very moral core of the notion of justice upon which contemporary international law rests. According to Buchanan, human rights are the moral foundation of the international legal order and ought to be its primary goal not only because of the natural duty of justice but also because they best articulate the demands of justice arising in the context of the existence of sovereignty as a universalised form of political organisation and from the existence of a global basic structure and its profound effects on lives of individuals. ${ }^{46}$ In Macklem's interpretation, human rights have a prominent role to play in the structure and the operation of international law because they monitor the legitimacy of political claims and actions to which the broader international legal order extends international legal validity. By imposing obligations on sovereign states and other legal actors to exercise the authority they receive from international law within their scope, human rights express what is required of the international legal order to enable it to acquire a measure of normative legitimacy. ${ }^{47}$

Consequently, forms of political organisation and claims to legitimate exercise of political power authorised by international law such as the right to self-determination and sovereignty cannot be morally interpreted separate from human rights. The importance of human rights for a normative interpretation of the scope right to self-determination and sovereignty over natural resources can also be highlighted by invoking the above-mentioned fact, namely that human rights and the right to selfdetermination have emerged in the same transformative period in world politics and the reform of international law and can be thus said to be co-original. As I argued above, the anticolonial reinvention of the right to self-determination and its normative foundations occurred in the context of the creation of the international legal system of human rights. Anticolonialism, to be sure, was a struggle for the independence and the collective liberation from the empire. It emphasised the right to collective self-determination and the independence institutionalised in sovereign statehood. However, the anticolonial reinvention of the right to collective self-determination revitalised the concern with human rights which, at the

\footnotetext{
46 See (n 16) 83-98. Natural duty of justice implies a limited obligation to contribute to creating structures and institutions that provide all persons access to just institutions which protect basic human rights.
}

47 Macklem (n 42) 11, 46. 
same time, helped to redefine self-determination's normative foundations as well as its internal content. ${ }^{48}$ The right to self-determination was named as the very first of all human rights, a threshold right, so to speak, in human rights covenants, binding international legal documents defining civil and political liberties and social and economic rights. At the same time, the right to self-determination was in this very context linked to national ownership of natural resources. ${ }^{49}$

This 'co-originality' of the right to self-determination and human rights and sovereignty over natural resources emerged, as Gilbert has shown, within a 'dichotomous' process of ascribing equal rights to sovereignty, including sovereignty over natural resources, to states and ascribing peoples and individuals rights on their own account, including rights of peoples to reclaim control over their natural resources. Concerning rights to natural resources, this dichotomy reflected two interconnected yet distinct agendas - the postcolonial agenda for a new international economic order that put the emphasis on state sovereignty over natural resources on the one hand, and the human rights and decolonialisation agenda which supported the rights of peoples to reclaim control over their natural resources on the other. However, the affirmation of sovereignty over natural resources in legally binding human rights instruments as the right of the peoples (not states) to 'freely dispose of their natural resources' clearly implies the emergence and prominence of a human rights-based approach to the scope of sovereignty over natural resources. ${ }^{50}$

What matters in the present contexts is that there is a mutually reinforcing link between the right to self-determination, sovereignty over natural resources, and human rights in contemporary international law. This link follows both from the complex entanglement of these norms of international law and from their being a part of a relatively coherent, internationally negotiated and accepted vision of both domestic and international justice for the plurality of territorially situated selfdetermining collectives which centres on their peaceful cooperation and individual human rights. Sovereignty over natural resources, as I showed above, is an inherent element of this notion of justice because it is a condition of collective political self-determination - both because

48 For this point see Wenar (n 11) 190-207, Reus-Smit (n 28) 153-60, 169-70, 180-7 and Schrijver (n 25) 49-56.

49 For yet another documentation of the fact that PSONR evolved in international legal order through its engagement with the human rights regime, see A Miranda, 'The Role of International Law in Intrastate Natural Resource Allocation: Sovereignty, Human Rights, and Peoples-Based Development (2012) 45(3) Vanderbilt Journal of Transnational Law 796, 798-800.

50 Gilbert (n 38) 317. 
in the absence of control over natural resources political independence is incomplete and because territorial groups are privileged in enjoying 'their' natural resources for their collective well-being. Human rights are similarly connected to the right to self-determination and resource sovereignty. While the right to self-determination is the condition of possibility of the exercise of human rights and the manifestation of their totality, human rights in turn specify the internal content of the collective self-determination. ${ }^{51}$ By the same token, they specify the internal content of resource sovereignty. Resource sovereignty, it can also be argued, helps to fulfil demands implied in social and economic human rights. ${ }^{52}$

Human rights thus ought to count in a normative account of sovereign rights to natural resources, especially in specifying substantive principles of justice inherent in them. Two dimensions of justice are prominent - the dimension of political legitimacy of the exercise of power and the dimension of the distribution of natural resource benefits. These dimensions are implied in the two main powers of decisional autonomy and ownership of natural resources which are held by self-determining groups. The discussion about these two dimensions of justice and their main substantive principles follows in the very last sections of this article.

\section{Political legitimacy}

The context which makes the political legitimacy account morally urgent concerns cases of the capture of natural resource wealth by illegal or illegitimate powers and the use of this wealth exclusively for the private benefit of small groups (ruling elites, oligarchs, private militias) and for unjust purposes - to sustain repression, authoritarianism, military rule, or to perpetrate violence. The extent of this problem has been documented by the literature on the resource curse and its moral outrageousness was highlighted by Leif Wenar. In particular Equatorial Guinea and its ongoing abuse of oil has become a notorious example: its president Teodoro Obiang who came to power unconstitutionally in a military coup and has maintained his power through political repression and poverty, has been accumulating his country's natural resources at will, using the revenues from the sales exclusively for his private benefit and to enhance his ability to sustain a repressive regime. His usurpation of the

51 This is Cassese's point (n 34) 15.

52 For more on the connection between human rights and rights to natural resources see P Gümplová, 'Rights to Natural Resources and Human Rights' in M Oksanen, A Dodsworth and S O'Doherty (eds), Environmental Human Rights: A Political Theory Perspective (Routledge, Abingdon, 2017) 85-104. 
country's sovereign legal title to natural resources is anchored in the fact of Obiang's violent coercion. ${ }^{53}$

There are many other cases of rulers who are accepted internationally as legally authorised to sell off that country's natural resources simply on the basis of their ability to maintain coercive control over a resource and a country's population. That a highly repressive and corrupt dictatorship which came to power unconstitutionally cannot be recognised to have a legitimate right to usurp benefits from the use of natural resources, especially not when it uses them to oppress its own people in radical ways, seems obvious. Such cases suggest there ought to be conditions and requirements for a legitimate exercise of power and there are conditions under which a state is entitled to all the powers, rights, privileges, and immunities ascribed to states by international law, including sovereignty over natural resources. When these conditions are not met, states and governments acting on their behalf are exercising their resource rights illegitimately. For reasons summarised in the previous section, I argue that human rights are uniquely positioned to provide the international standard of legitimacy of the exercise of sovereign rights to natural resources. States respecting and protecting human rights of their people legitimately exercise their sovereign resource rights. States which systematically and persistently violate human rights do not legitimately exercise their sovereign resource rights.

How to specify and apply the human rights approach to legitimacy of the exercise of rights to natural resources was outlined systematically by Leif Wenar. ${ }^{54}$ Having recognised the continuity, the extent, and the urgency of the abuse of natural resources, Wenar proposed a twofold strategy. On the one hand, he emphasises that the people are the real and ultimate holders of sovereign rights over resources and that they collectively hold rights of ownership of natural resources and hence the right of authorisation of all decisions concerning them. On the other hand, he employed the language of qualified and limited state sovereignty. Invoking human rights as the very moral core of international law, he suggested they represent the set of principles that define the permissible scope of state power and the conditions for the legitimacy of its exercise, including sovereignty over natural resources. This important role of

53 L Wenar, 'Property Rights and the Resource Curse' (2008) 36(1) Philosophy \& Public Affairs 6.

${ }^{54}$ For a detailed and comprehensive analysis of Wenar's approach see P Gümplová, 'Popular Sovereignty over Natural Resources: A Critical Reappraisal of Leif Wenar's Blood Oil from the Perspective of International Law and Justice' (2018) 7(2) Global Constitutionalism 173. 
human rights can be further reinforced by exposing their link to the twin rights of self-determination and permanent sovereignty over natural resources. ${ }^{55}$

Since the authorisation and consent to government's decisions about resources are the key principles of popular resource sovereignty, Wenar emphasised political rights and civil liberties as the key subset of human rights relevant for the assessment of the legitimacy of a government's decisions about resources. These rights secure citizens' access to information, the possibility of deliberation, and enable citizens to express their views in ways that have an impact on state decisions concerning natural resources. These rights have to be guaranteed if the people are to be meaningfully exercising their right to authorise decisions about resources - their resource sovereignty. To determine the degree of compliance of a given state with political and civil rights, Wenar proposed we can rely on global NGOs and their monitoring, for example on Freedom House's political rights and civil liberties rating of 6 or 7 and the 'not free' status. These are reliable indicators that political rights in a given country are very restricted or non-existent. The absence of civil liberties and political rights means no authorisation is given by the people, and hence resource sovereignty is exercised illegitimately by a state. ${ }^{56}$

Relying on independent metrics based on commonly accepted set of standards concerning rule of law and human rights, countries can thus be publicly and internationally assessed in light of their compliance with human rights, especially civil and political rights. Toward resource-rich exporting countries which persistently disrespect human rights, trade and economic policies of disengagement ought to be adopted. An exemplary Clean Trade Act Wenar proposes is an act which prohibits commercial trade with vendors in countries which do not meet the minimal accountability criteria and where citizens have no civil liberties and basic political rights, for example by making it illegal to purchase resource from disqualified countries or by denying financial, commercial and judicial facilities to vendors of a disqualified country's resources. Clean trade legislations can be complemented by anti-corruption and transparency measures, resource validation schemes, embargoes and sanctions, or revenue distribution schemes many of which are currently debated in international and domestic policy circles. ${ }^{57}$

\footnotetext{
55 See Wenar (n 11) 143-4, 174, 196, 213-14.

56 See Wenar (n 11) 220-45.

57 See Wenar (n 11) 281-334.
} 
While Wenar's specific clean trade legislative proposals are yet to be adopted more extensively in practice, ${ }^{58}$ there are applications of a human rights approach concerning legitimacy of governments' decisions about natural resources. Indigenous peoples' procedural right to free and prior informed consultation or consent (FPIC) to extractive or development projects that affect them or their territories is an outstanding example. FPIC has been recognised in The United Nations Declaration on the Rights of Indigenous Peoples (UNDRIP) and has its genesis in the application of general human rights precepts. It is considered to be a corollary of indigenous peoples' rights to natural resources (they include substantive rights to own, occupy, use, and control their traditional territories, lands, and resources) which have been framed, asserted, and recognised as human rights. Recently, FPIC which allows indigenous peoples to give or withhold consent to a government's project at any time was applied in the InterAmerican system of human rights. According to the Inter-American Court's jurisprudence, indigenous groups now have enforceable right to consultation and consent to a development project that implicates their lands and resources. ${ }^{59}$

\section{Distribution of natural resource benefits}

The question of the just allocation of resource rights and benefits and burdens flowing from them in an intrastate context is an equally extensive and urgent problem. States often pursue large-scale extractive or development projects which create adverse effects and ignite a range of concerns regarding an unjust or unfair allocation of benefits and burdens to multiple constituencies within the state - the people as a whole, citizens individually, historically marginalised groups such as indigenous people, rural poor, or subsistence farmers, all with legitimate distributive claims. ${ }^{60}$ There have been countless cases of bad and inequitable extraction projects and deals with multinational corporations which caused immense and permanent environmental harms and brought no economic benefits for the

58 An example is the Clean Diamond Trade Act adopted in 2003 by GW Bush's Administration which requires that all diamonds imported to the United States or exported from the US have a Kimberley Process Certificate - a certificate that their mining does not fuel conflict in the country of origin.

59 In the Saramaka Peoples $v$ Suriname case, the Inter-American Court noted that 'regarding large-scale development or investment projects that would have a major impact within Saramaka territory, the State has a duty, not only to consult with the Saramakas, but also to obtain their free, prior, and informed consent, according to their customs and traditions'. Saramaka Peoples $v$ Suriname, Judgment, Inter-Am. Ct. H.R. (ser. C) No. 172, 134, 28 November 2007.

60 See (n 49) 802. 
country's people. To name just one example: Belo Monte Dam, one of the largest dams in the world currently under construction in Brazil, raises a number of concerns concerning huge social and environmental costs involuntary displacement, violation of indigenous rights, adverse impacts on fishing and farming, water pollution, deforestation, greenhouse gas emissions, and the loss of biodiversity.

These and many other similar cases raise questions concerning states' ability to exploit natural resources for national economic development and the benefit and well-being of the people as a whole and their ability to fairly distribute and balance benefits and burdens among various communities and constituencies. Theories of natural resource justice have not addressed these issues and their proposals have no bearing whatsoever on them. ${ }^{61}$ This void is explicable by the above-discussed methodological bias of the normative theory and philosophy of justice and their categorical refusal of sovereignty over natural resources as unjustifiable on any moral grounds on the one hand; and by the commitment to justice's global scope, especially when it comes to distribution of natural resources, on the other hand. However, the inability of theories of natural resource justice to address a state's use of natural resources from the perspective of fair and equitable distribution of benefits and burdens in the intrastate context is hardly justifiable.

The problem of justice of the intrastate allocation of resources and benefits arising from their use has to be made part of a normative conception of resource rights. Indeed, the creation of the system of sovereign rights to natural resources was primarily driven by distributive aspirations. As I demonstrated, the system was justified not only as a corrective of colonialism but as a necessary prerequisite for the national development of a country and the social and economic welfare of its people. These goals - explicitly albeit generally articulated in relevant international legal documents which express demands that states exploit their natural resources for national social and economic development and the benefit and well-being of their people ${ }^{62}$ - reflected a shared view that resource

${ }^{61}$ Based on the moral imperative that each person is entitled to an equal portion of the value of world's natural resources, Hillel Steiner has for example proposed the establishment of The Global Fund into which states pay 100 per cent tax on the value of unimproved natural resources in their territories, to be then globally redistributed in the form of global basic income. H Steiner, 'The Global Fund: A Reply to Casal' (2011) 8(3) Journal of Moral Philosophy 328.

62 The Resolution on Permanent Sovereignty recognises in its very first article that 'the right of peoples and nations to permanent sovereignty over their natural wealth and resources must be exercised in the interest of their national development and of the well-being of the people of the State concerned'. 
sovereignty is indispensable for a country's economic development and for the enhancement of domestic social justice which, in turn, boost political independence. Domestic economic development based on resource exploitation was also seen by many developing countries as a necessary prerequisite for redressing global economic disparities between developed and newly independent and developing countries.

These substantive economic and distributive ends associated with the institution of PSONR - the well-being of the people and the national development - imply that states are prescribed actions aimed at the promotion and realisation of these outcomes and that they are also obliged to refrain from abuses of natural resources. They articulate a standing demand on states to make sure the population enjoys the benefits arising from the resource exploitation and sales and that the people are the beneficiaries of resource projects and deals with other states or companies. When a government exploits its natural resources in the exclusive interest of a small group, excluding the vast majority from enjoying benefits or when it surrenders control over its natural resources to another state or foreign company without ensuring that the people are the beneficiaries of such arrangements, it abuses its power and acts unjustly. ${ }^{63}$

To determine states' resource-specific distributive obligations vis-à-vis their populations in greater detail is, however, necessary. This task can and ought to be achieved again by recourse to human rights. International human rights law has in fact already played an important role in the discourse about resource allocation and about equitable distribution of resources within state borders. This is reflected, again, in the process of the recognition of rights of indigenous peoples to land and resources. These rights have not been pursued as a matter of sovereignty and statehood but as a matter of human rights. Rights to control and use the lands the indigenous people have traditionally occupied have been framed as an issue of attachment, the preservation of communal identity, culture, religion, and traditional modes of subsistence. Indigenous people actively engaged in the international human rights system which has responded to their claims and framed their entitlements as human rights to culture. As a result of the process of international legalisation of indigenous rights, states now bear human rights responsibilities toward indigenous peoples to grant them substantive rights to land and resources and to obtain their consent to engage in an extractive project on their lands. ${ }^{64}$

63 See (n 34) 56. See also E Duruigbo, 'Permanent Sovereignty and People's Ownership of Natural Resources in International Law' (2006) 33 George Washington International Law Review 67.

64 See (n 49) 811-16. 


\section{PETRA GÜMPLOVÁ}

The emerging human rights jurisprudence regarding the rights of indigenous peoples demonstrates that human rights are the most potent to address the issue of distribution of benefits and burdens arising from resource use in an intrastate and possibly also in interstate context. They can serve as a platform for an analysis of a proper distribution of natural resources and resource benefits not only to historically marginalised groups. Clearly, human rights lend themselves to identification of a set of core duties of states with regard to natural resource benefits allocation toward individuals. These duties follow directly from social and economic human rights. As an indivisible part of human rights norms, social and economic rights define basic human material and welfare needs and create obligations for states to provide food and social security, basic health care services, education, access to housing and adequate standard of living, and protection against severe poverty. ${ }^{65}$

The fulfilment of these rights ought to be reflected in domestic policies and decisions concerning the allocation of resource benefits. As a result of their duties to uphold social and economic rights, states need to guarantee that individuals have access to sufficient shares of those natural resources which are crucial for their survival and the most basic rights of subsistence, such as water and land. Water management policies and distribution of land rights need to reflect these basic entitlements to sufficient shares of these natural resources. ${ }^{66}$ Benefits arising from the exploitation of minerals, fossil fuels, and other economically valuable resources ought to be allocated in such a way that enhances the realisation of citizens' human rights, especially their social and economic rights. ${ }^{67}$ At the same time, the universality of these rights alert us to the needs of the people worldwide to whom any 'surplus' benefits could be allocated on the basis of the same human rights based distributive logic of natural resource justice.

Of course, how exactly these goals are achieved is subject to complex economic policies and processes, as well as questions of how to distribute other goods, entitlements, and services. To insist that there are distributive

65 See arts 11-13 in International Covenant on Economic, Social and Cultural Rights and 'The Maastricht Guidelines on Violations of Economic, Social and Cultural Rights' (1998) 20(3) Human Rights Quarterly 691.

66 As Gilbert shows, human rights-based normative framework can be directly instrumental for reforms concerning the redistribution of land rights and creating community property systems (e.g. for fishing and forest management), the development aimed at fair and equitable intra-state and inter-state benefit sharing, taxation schemes, foreign investment regulation, indigenous rights protection, biodiversity conservation, water rights, and climate justice. See Gilbert (n 11) 34-176.

67 This applies to burdens as well - the burdens of resource extraction should be distributed in such a way so as not to jeopardise human rights. 
ends inherent in the system of sovereignty over natural resources which limit states' prerogatives over resources is, however, an important achievement. These limits complement the procedural legitimacy conditions for governments' decisions about natural resources. Both legitimacy of the exercise of resource rights and the specification of distributive goals ought to be part of a comprehensive reinterpretation of state's rights to natural resources in normative terms. And both can be related to human rights international legal norms which have the capacity to articulate global standard of legitimacy and justice for territorial collectives and involve standards of assessment and mechanisms of monitoring and enforcement which can facilitate feasible reforms. On the basis of human rights in their totality, a broad and practicable notion of natural resource justice can be defended, such that includes both legitimacy conditions for the decisionmaking about resources and distributive requirements concerning benefits and burdens flowing from their use.

\section{Conclusion}

Motivated by the necessity to critically address and correct unjust uses of natural resources by states, this article argued for a possibility of the interpretation and reinvention of sovereignty over natural resources according to its own inherent moral principles. Relying on the historical reconstruction of the origin of the system of sovereign rights to natural resources and moral interpretation of postwar international law and its core norms, most importantly the right to self-determination and human rights, I argued that sovereignty over natural resources is internally limited in two dimensions - in the dimension of political legitimacy of decisions concerning natural resources taken by a state and in the dimension of the distribution of benefits arising from the use of natural resources. In each dimension, I argued, human rights could play a key role in determining and circumscribing states' prerogatives over natural resources. Not only do human rights provide criteria of political legitimacy of governmental power and hence conditions of rightful exercise of resource rights; they also help to define substantive distributive duties with regard to natural resources, obliging states to use natural resources for the social and economic benefit of its people. 